\title{
SPATIAL CO-MANAGEMEN'T OF INDONESIAN FLOODPLAIN RIVER FISHERIES
}

\author{
Daniel D. Hoggarth ${ }^{*}$, Mark A.Thomas ${ }^{*}$, Achmad S. Sarnita ${ }^{* *)}$, and Ondara ${ }^{* * *}$
}

\begin{abstract}
An interdisciplinary investigation was made on the mechanisms underlying the development of local management systems for floodplain river fisheries in Sumatera. The five study sites varied in the hydro-morphology and sizes of their river systems and in their spatial relationships between waterbodies and villages. Interviews and formal meetings with Fisheries Department staff, fishermen, traders and village leaders clarified the relative objectives of the different players in the fisheries towards profit maximisation, resource sustainability or social benefits; and their ability to achieve their aims in different hydrological and social situations. Strong local management regimes were found at all five sites, clearly adapted to local conditions. The site with the largest and most remote floodplains was managed for profit through an auction system. This contrasted with the other sites, where smaller, more locally accessible waterbodies were managed with more social objectives by the adjacent villages. Where permanent dry-season floodplain waterbodies were associated with villages, it was found that these were managed for the long term sustainability of local resources, especially using reserves. In contrast, main river habitats with migratory fish stocks more widely shared between communities were not managed in any way. Due to the complexity of factors affecting floodplain fisheries, and their variability between different locations, it is recommended that further consideration be given to a unified co-management strategy including elements of both local spatial control by communities for the resident floodplain 'black-fish' species, and a wider contribution by regional fisheries departments for the migratory riverine 'white-fish'.
\end{abstract}

KEYWORDS: co-management, community management, floodplain river fisheries, reserves, licensing

\section{INTRODUCTION}

The management issues for floodplain fisheries can be reduced to two main components: withinseason management, relating to the seasonal trade-offs between the catches of different fishing gears, and the social groups that operate them; and between-season management, relating to the long-term survival and reproduction of different components of the stock the issue of sustainability.

The within-season distribution of fishing effort is particularly important in floodplain fisheries because the expansion and contraction of the flooded area, the sharp seasonal increase in fish biomass and the migratory behavior of the fish mean that the profitability of the fishery is highly sensitive to the type and timing of fishing effort. As in any fishery, the capture of young fish too early in the season prevents them from achieving their growth potential and so can reduce the total catch value. In floodplain fisheries, delaying capture may also be beneficial as a result of reduced costs as the fish are more easily caught in the drawdown and/or low water seasons.
The impact of within season gear interactions on potential incomes is recognised by fishermen, who compete for the best fishing locations in any unregulated environment. Often, far more fishing effort is used than needed to take the maximum potential catch (Hoggarth \& Kirkwood, 1996). These conflicts, and the resulting loss in profitability, are best avoided through some form of spatial control. This can be achieved either by the leasing of discrete areas within the fishery, or by any other socially accepted mechanism, such as the allocation of fishing spots according to historical precedent or through lotteries.

The between season sustainability of floodplain fisheries depends on local hydrological conditions and the pattern and level of fishing effort. Local hydrology affects fish survival as it determines which gears might be used and how successful they are likely to be. Most gears can only be used within certain ranges of depth, river width and current speed. In some areas, shallower rivers and floodplain depressions can be fished out almost completely every year, increasing the chances of recruitment overfishing. Elsewhere they can only

\footnotetext{
Marine Resources Assessment (Xroup Lad (MRAG), 47 Princes Gate, London, SW7 2QA, UK

**) Research Institute for Freshwater Fisheries

**) Prembang Research Station for Freshwater Fisheries
} 


\section{D.D. Hoggarth, M.A. Thomas, A.S. Sarnita, and Ondara}

be fished out occasionally, when water levels fall low enough, or not at all; here stocks are more likely to survive. The challenge for between-season management is to ensure that enough fish survive somewhere in each local area to sustain the fishery in following years.

As a fishery develops, both within and between season management usually become necessary. The priority given to the two management needs varies, however, among the different interest groups. Fishermen will thus agree to the restrictions on access arising from spatial control of their fishery, sometimes because they have little choice, but also because they often recognise the costs to themselves of continual disputes. They are, however, less likely to moderate their catch of overexploited species unless they believe that their actions will encourage others to behave similarly Leaseholders, whose individual behavior influences only a fraction of the stock and whose uncertain tenure further undermines their incentive to take a long term view are more interested in within-season management issues, even though they may be aware that collectively their actions are unsustainable. Fisheries departments or policy makers, whose mandate extends to the entire stock, are more concerned with sustainability but frequently lack both the knowledge of local conditions and the resources necessary to manage the fishery effectively.

Local communities, on the other hand, tend to be concerned with both sets of management issues. Within-season management avoids both the dissipation of fishermen's incomes through excessive levels of effort and conflict. Between season management can ensure that the flow of incomes to members of the community is sustained. Moreover, strong local participation in fisheries management decisions has a number of distinct advantages. The distributional tradeoffs implicit in alternative non Government controlled management regimes can be set against local socio-economic priorities. Communities with high unemployment might thus prefer to widen the fishing opportunities available, even if this reduces the overall profitability of the fishery. Also, local communities or fishermen's organizations often have the means to deal with the practical problems of management, for example by encouraging collective modifications in behavior, imposing social sanctions on rule breakers or acting as arbitrators in disputes. Though well equipped for a management role, local communities can not, however, be the solution to all problems, particularly where the resources they exploit are shared with other communities.

Against this conceptual background, this study was undertaken to determine how river floodplain fisheries in southern Sumatera are currently managed by both formal management agencies and local communities. Significant variability was found in the local management styles at five study sites. However, using an interdisciplinary approach to the assessment of the physical/ ecological and social/cultural features of the sites, the apparently complex management issues were clarified.

\section{METHODOLOGY}

Comparative information was collected during field visits in May 1996 to five case study sites in Jambi and South Sumatera provinces ${ }^{1)}$ on the Island of Sumatera (Figure 1). A fourman research team spent between one and five study days at each of the field sites. During the field trips, a mixture of informal interviews, semistructured interviews, and formal meetings were arranged with people connected with each fishery, in both field and office situations. The categories of respondents included Fisheries Extension Service (Dinas Perikanan) staff at both provincial and kabupaten levels; village leaders both administrative and traditional (adat); fishing leaseholders; fish traders; and group and individual fishermen.

At each study site, largely qualitative information was collected on (1) the morphology of the fished waterbodies, (2) the spatial relationships between waterbodies and human settlements (3) the types of fish species exploited, (4) the fishery management mechanisms in use, and (5) the resulting fishing practices. Particular attention was given to the spatial aspects of the allocation of use rights (e.g. by licensing), and the prevention of overfishing (e.g. by the use of reserves, or by localised gear restrictions). The ecological and management differences between the study sites are described in the following sections, and summarised in Table 1

\footnotetext{
The Indonesian government alministration system is based on the following four levels: propinsi (province); kabupaten (regency): kecrumatan (district): desa (village)
} 


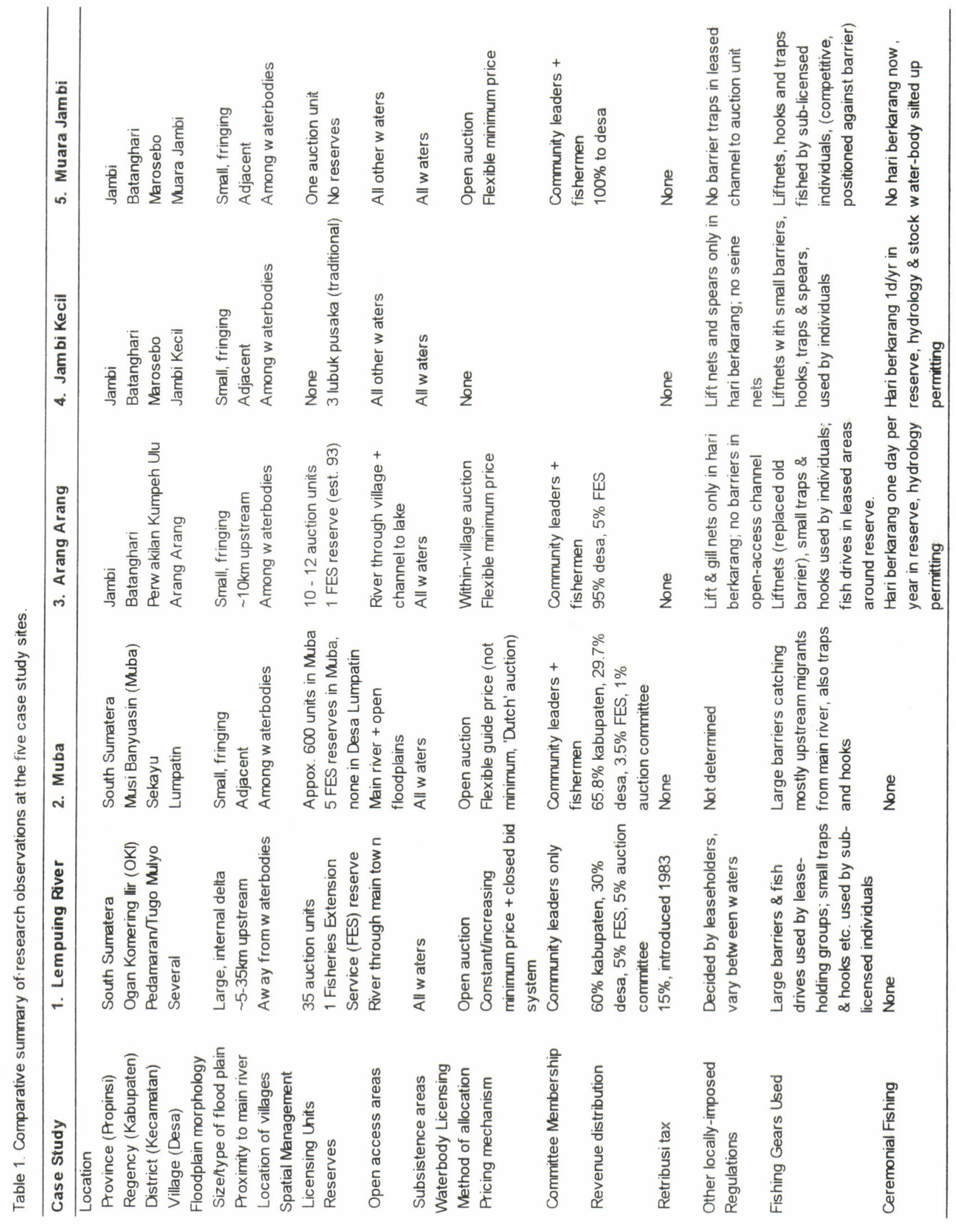




\section{RESULTS AND DISCUSSION}

\section{Floodplain Morphology and Human Settlement}

The five study sites differed significantly in the size and morphology of their river floodplain systems, and in their patterns of human settlement (see Table 1 for all results).

The first study site, Lempuing River, has one of the most productive inland fisheries in Indonesia, and has been the subject of a number of earlier studies (eg. Vaas et al., 1953; Giesen \& Sokotjo, 1991; Hoggarth \& Utomo, 1994). Though the Lempuing is relatively small $(15-40 \mathrm{~m}$ wide), its high productivity derives from a $200 \mathrm{~km}^{2}$ area of 'lebak' floodplain, containing nineteen 'lebung' lakes, up to 390ha in size (Figure 1).

The other four study sites were located on relatively smaller, less productive floodplain systems, though mostly closer to large main rivers of several hundred metres in width

At study site 2 in Kabupaten Musi Banyuasin or 'Muba' (Figure 1), a narrow secondary river, the 10-20m wide Lumpatin River, flows from minor floodplains without permanent lakes or other dry-season habitats, directly into the broad Musi River, passing through the village of Sekayu.

Three study sites were also visited around the Batanghari River near Jambi (Figure 1). Study sites 3 and 4 were located on separate, $\sim 30 \mathrm{~m}$ wide side channels of the Batanghari. In addition to the river waters of the Kumpeh Channel River, Arang Arang village or 'desa' has exclusive control over a lake, Danau Arang Arang, with a dry season area around 20ha. Desa Jambi Kecil (study site 4), has fishing rights to part of the Berembang Channel River, which retains permanent water in all dry seasons, particularly in its deep ' $l u b u k$ ' pools. The fifth study site in Desa Muara Jambi lies alongside the main Batanghari River, downstream of Jambi Kecil. There are no significant floodplain or lake habitats close to Muara Jambi, but the village owns a lake called Danau Gerang. This lake, $17 \mathrm{~km}$ away from the village (Figure 1), was transferred from its original village owners in compensation for a murder in ancient times.

The settlements of Sekayu, Arang Arang and Jambi Kecil are thus all close to their main fishing grounds. The villages at the other two sites are less clearly associated with the fished waterbodies. Muara Jambi is remote from its
Danau Gerang for the above historical reason. The Lempuing River has no permanent settlements among the waterbodies due to the depth of the floodplain waters and the absence of permanent roads. Most of the Lempuing fishermen live in Pedamaran, downstream of the fishing grounds (Figure 1) and build temporary huts on the waterbodies they lease through the auction system (see later).

\section{Fish Migrations}

Floodplain fish species have adapted their behaviour to the hostile conditions in residual, dry-season waterbodies in different ways. Some species, referred to as 'white-fish' in the classification of Welcomme (1985), return to the main river channels as the floods recede. Others, 'black-fish', have developed anatomically to deal with deoxygenated water and remain in the floodplain pools.

The whitefish species, such as the silurid catish Mystus nemurus should have 'authority' and the giant freshwater prawn Macrobrachium rosenbergii are the most 'shared' stocks, as their extensive migrations take them between the spatial fishing units of different fishermen (MRAG, 1997). Whitefish tend to be most vulnerable to capture during their migrations through the channels where the floodplains drain back into the main rivers. The black-fish species, such as Helostoma temmincki and Osteochilus hasselti, are more confined within single waterbodies, or at least within a limited range, and are most vulnerable to capture in the dry season.

The Lempuing and Jambi sites, with their mixture of rivers and floodplain lakes, produce catches with more than 30 different fish species (Hoggarth \& Utomo, 1994), including both black and white-fish. At the more riverine Sekayu site, white-fish species dominate the catches, while black-fish are comparatively rare.

\section{Fishery Licensing and Auction Systems}

Four of the five study sites (not Jambi Kecil) were managed by the licensing of defined waterbody units, such as floodplain lakes or river sections. The number of waterbodies licensed ranged from the single Danau Gerang in Muara Jambi up to 35 units for the productive Lempuing River. At all sites, licenses were auctioned on a temporary basis, for a one year period. Apart from this one similarity, the licensing and auction systems differed significantly between the sites in 


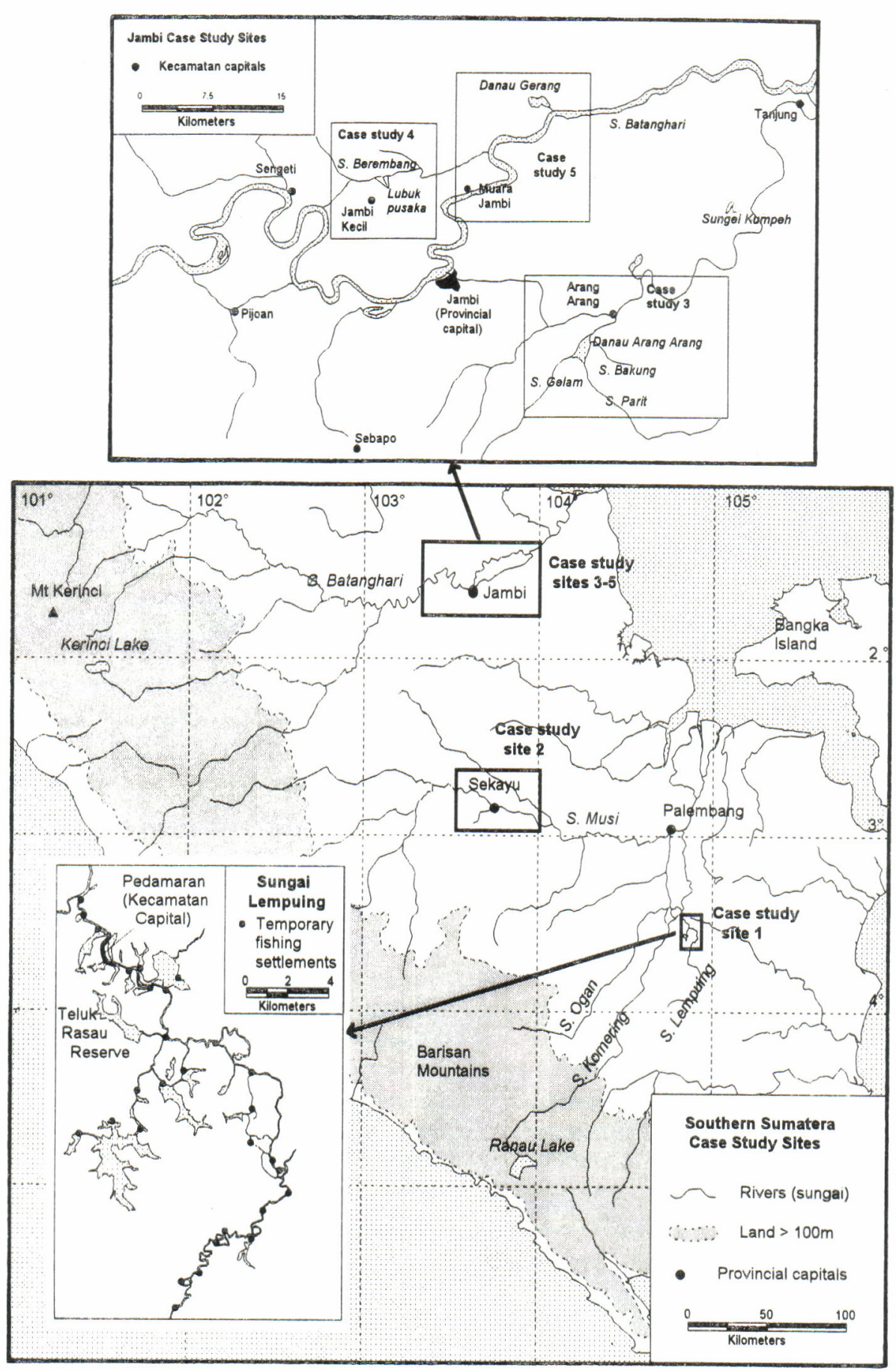

Figure 1. Location, river morphologies and human settlements of the five case study sites in Southern Sumatera, Indonesia 


\section{D.D. Hoggarth, M.A. Thomas, A.S. Sarnita, and Ondara}

the following five respects: revenue distribution; access to bidding; license pricing mechanisms; auction committee membership; and habitats licensed.

Licensing may raise substantial incomes for fishery administrators. In Kabupaten OKI, which includes the Lempuing study site, total license fees were $\mathrm{Rp} 890 \mathrm{~m}(\sim 380,000)$ in 1996 . In OKI and Muba Kabupatens, at least $60 \%$ of such auction revenue was received by the kabupaten administrations, contributing up to $50 \%$ of the total kabupaten incomes. Only 30\% of the revenue was distributed to desa level administrations in these sites, compared to $95-100 \%$ at the Jambi sites. An additional 15\% 'retribusi' tax was also levied on license fees in OKI.

At the Lempuing, Muba and Muara Jambi sites, the auctions were open to all bidders, while at Arang Arang, bidding was limited to village members only.

License prices were set in OKI by an auction committee at last year's sale price plus a fixed percentage of up to $15 \%$ per year. Unsold license units were available to 'sealed bids' after the main auction. At the other sites, license prices were more flexible, with a guide price being set for the auction sometimes at lower prices than previous years.

At the Lempuing site, the auction committees responsible for setting license guide prices included only fishery department staff and administrators at kabupaten and kecamatan levels. At the other sites, the auctions were organised at village level, and fishermen were also represented on the committee to advise on the current status of resources and the feasibility of alternative guide prices for each waterbody.

Finally, for the Lempuing and Sekayu sites in the South Sumatera, the auction system allocated fishing rights to almost all waterbodies, including their floodplains. At the Jambi sites, only a sub. set of the dry season pools and river sections was licensed, leaving the floodplain areas open access for all fishers.

Due to the uncertainty of future ownership and the migrations of fish out of their waters, licensed fishermen at all sites exploited their resources heavily to maximise their catches. Licensing systems do not provide any incentives for long. term conservation of resources. The following two sections describe the additional 'technical' regulations used at each site to control fishing activities and conserve fish resources.

\section{Reserves and Ceremonial Fishing}

Reserves were used as conservation measures at three of the study sites. In the Lempuing River, the 126ha 'Teluk Rasau' Lake (Figure 1) was not included in the annual auction by the Fisheries Extension Service. The enforcement of the reserve was limited, though, and some fishermen were cynical about its effectiveness and value. Reserves were not used in the riverine Sekayu study site, though they had been recently implemented by the Kabupaten Muba Fisheries Extension Service in other nearby lake waters.

In contrast, traditional reserves were strongly supported by the local communities at two of the Jambi villages studied, and supported by ceremonial fishing practices.

Fishing on Danau Arang Arang reserve in Jambi is traditionally restricted to one ceremonial day each year, the 'hari berkarang'. This major communal event, attended by local dignitaries, takes place during the low water period, on a Sunday, to allow the maximum participation of village members. Gill nets and seines are forbidden, and the fish are driven into a capture chamber to be fished by relatively inefficient cast nets. Even with these limitations, catches are large, ranging from 2 to 10 tonnes.

In the nearby Desa Jambi Kecil, fishing is open access in all waters during the whole year, except in the three 'lubuk pusaka' or sacred pools of Sungei Berembang. These lubuk pusaka are restricted as dry season reserves, though fishing is again allowed on ceremonial 'hari berkarang' days. Participation in the hari berkarang is restricted to village members and higher district leaders. Only relatively ineffective spears and lift and jump nets are permitted on these days, and the net fishing positions are determined by the ancestral rights of community members.

Both the Jambi hari berkarang ceremonies have been practised since before living memory, and have some religious significance, with fish stocks being regarded as the gift of the ancestors. The annual decision to fish these reserves is based on their perceived stock sizes, since the catches must be large enough to demonstrate the high status of the village to the invited dignitaries. On average, the Jambi Kecil lubuks were only fished approximately once every three years, and local chiefs estimated that only a third of the fish in the pools might actually be caught in the one afternoon of fishing. 
Local Fishing Regulations and Fishing Gear Use

Indonesian government technical regulations on fishing gear use in inland waters are restricted to bans on the use of poisons, electric fishing and explosives, and a few mesh size regulations. In these artisanal and rural fisheries, such regulations are difficult to enforce. There are no regulations which protect fish stocks against the many other highly effective gears such as barrier traps and dry season fish drives.

The choice of fishing gear use at the fully licensed Lempuing River and Sekayu study sites is thus the sole responsibility of the licenceholding fishermen. At these sites, seven main classes of fishing gears are used (Hoggarth \& Kirkwood, 1996). In the ebb season, well financed groups of fishermen usually use expensive net and flume traps mounted in heavy wooden barriers, spanning the full widths of their rivers and channels (Hoggarth \& Utomo, 1994). In the dry season, if water levels fall low enough, the same group fishermen also use active fish drives to catch as many of the remaining fish as possible. Individual fishermen, sub-licensed by the groups, use smaller, cheaper gears including various forms of small lift nets, gill nets, cast nets, portable traps and hooks.

In the smaller Jambi sites, fishing communities sometimes make their own local gear regulations to conserve their stocks. These are particularly associated with the reserves and 'hari berkarang' ceremonies described above, but also serve to reduce conflicts in open access areas

At the Arang Arang site in Jambi, fishing rights are auctioned for the three inflow channels of the reserved Danau Arang Arang, while its outflow channel to the Kumpeh River (Figure 1) is open access. The inflowing river sections are intensely exploited by their license holders, using the effective barrier traps and seines found in the Lempuing. These gears are, however, banned on the unlicensed outflow channel, which is shared by up to 50 village fishermen using lift nets and portable traps.

\section{Interpretation of Results}

This discussion attempts to interpret the management systems and exploitation practices used at the five sites, based on their physical and social characteristics.

The greatest differences in management styles were observed between the most profit-oriented
Lempuing River site and the more communityoriented Jambi sites.

In the Lempuing River, the spatial licensing system is organised by the kabupaten and kecamatan level administrations. The kabupaten have a high stake in maintaining the auction system, due to their dependence on revenues obtained from it. Several key points about the structure of the auction system confirm its focus on revenue generation. Firstly, the auction is open, allowing the possibility of high bids from rich traders outside the local area. Secondly, the guide prices are set by an administrative committee, with no fishermen's representative, and are increased on a regular basis. Thirdly, additional funds are raised by the $15 \%$ 'retribusi' tax, imposed in OKI since 1983 , despite local objections

In addition to raising local government revenues, the Lempuing licensing system also has some clear within-season benefits for the fishermen. It delegates authority for the regulation of fishing effort to the license holders for the whole year. This reduces the potential for conflict and enables fishermen to use the productive barrier and driving gears to catch fish in the drawdown and dry seasons. In an open access situation, such gears may be unproductive if too much of the catch is taken before their operating seasons.

The Lempuing management system thus has economic and financial benefits, and prevents conflicts for both the administration and the fishing community. Apart from the Teluk Rasau reserve, though, the system does little to guarantee the sustainability of the fishery. Whitefish are caught in large numbers in the barrier traps and black. fish are targeted in the dry season fish drives. Total catches are still high at the present time (Hoggarth \& Kirkwood, 1996), but many of the most valuable fish species are becoming increasingly uncommon (MRAG, 1997).

In the Jambi study sites, the management styles observed suggest a greater focus on betweenseason sustainability issues for the benefit of local communities.

The organization of the Jambi auctions at desa level, and the restriction of bidding to village residents may reduce total revenues by preventing high bids from rich outsiders. However, they have the advantage that all the incomes from the fishery stay in the desa. Conflicts are also reduced by the accountability of local people, and the Arang Arang community appears happy with the current balance of reserved, open access and licensed waters. 


\section{D.D. Hoggarth, M.A. Thomas, A.S. Sarnita, and Ondara}

The Jambi Kecil lubuk pusaka and the Arang Arang reserve lake are clearly managed by these villages for the purpose of long term sustainability. The hari berkarang in these waters take a limited catch in an efficient manner, and with social equity promoted by the ceremonial participation of all the village households. By limiting the type of fishing and its duration to one day or less per year, the villages reduce the chance that their local black-fish species will be overexploited. According to the village elders, fisheries within the local area continued to be healthy because their dry season stocks were only fished for one season out of three.

This difference in approaches between these three study sites may be simply explained by the fact that the Jambi Kecil and Arang Arang fishermen live permanently among their small waterbodies, while the Lempuing River fishermen are only temporarily associated with their waters in the years of their licenses. As described by Ostrom (1990), communities may only be expected to take responsibility for those natural resources for which they have exclusive ownership within clearly defined boundaries. In this regard, the Lempuing River lake district may be seen as too large for individual management by its many fishers, necessitating the management role of a higher authority. The high potential income from this major fishery then appears to have directed the management style of that authority more towards profit maximisation than resource conservation.

This spatial viewpoint is supported by the absence of reserve waterbodies and ceremonial fishing in the Muara Jambi study site. Due to the remoteness of Muara Jambi's only lake, Danau Gerang, the status of such a reserve may be impossible to enforce by the Muara Jambi community. Alternatively it may simply not be regarded as one of their ancestral resources or local responsibilities.

A spatial viewpoint is further supported by the attitudes of the fishing communities towards the relatively immobile black-fish species most resident in their waters, and the riverine white-fish species, more shared with other communities in the catchment. The Arang Arang and Jambi Kecil Villages thus protect the blackfish species in their reserves, but take no steps to conserve the riverine white-fish of the secondary Sungei Kumpeh or the main Batanghari River. In Sekayu, similarly, there are no fishing restrictions for the mostly white-fish species caught in the village's waters, even though the village straddles the Lumpatin River
In summary, a community's incentive for the sustainable management of riverine fisheries appears to be strongly but simply influenced by the degree of control that it has over its resources. Where communities have traditional associations with local waterbodies, they have been found to manage them for the sustainable benefits of community members. Where resource control is shared with other communities, either for whitefish species or in large or remote waterbodies, communities managed primarily for short-term financial gain rather than long-term stability. While it is clear that small communities may be encouraged to take responsibility for their local fish stocks, the more shared resources may only be conserved by concerted joint actions, under the regional coordination of higher 'catchment management' authorities (Caddy, 1982).

\section{CONCLUSIONS}

Using a case study approach, this research has shown that the management of Sumatera river fisheries is dependent on the detailed local relationships between river morphologies, the behaviours of fish that inhabit them, and the distribution of local communities among the waterbodies.

In view of the complexity of factors affecting floodplain fisheries, and their variability between different locations, it is recommended that a unified inland fisheries management strategy should include elements of both spatial control by local communities for their resident floodplain black-fish species, and a wider contribution by regional Fisheries Departments for the migratory riverine white-fish. Such a co-management strategy should recognise and take advantage of the local management already present in traditional cultures. A shared approach would also remove some of the difficulties faced by the Fisheries Extension Service trying to impose new administrative regimes from their centralised offices, get constrained by limited resources for field-based monitoring and enforcement (Bailey \& Zerner, 1992).

The actual contribution to be made by the Fisheries Extension Services for the management of the riverine white-fish is not yet clear. Until effective conservation measures can be found, which have the support of local communities, the highest priority should be in monitoring stocks to determine when active management is necessary. Whatever measures may eventually be recommended, these should be applied in a spirit of co-management, and should not be at the expense of the existing and 
successful strategies used by communities to conserve their local black -fish stocks.

\section{ACKNOWLEDGEMENTS}

This paper was written with the support of the UK Department For International Development (DFID) Fisheries Management Science Programme (FMSP) Project R5953 'Fisheries Dynamics of Modified Floodplains in Southern Asia'. The authors are particularly grateful to all those respondents, in Dinas Perikanan and the five fishing communities, who generously provided both their time and many of the insights reported in this paper.

\section{REFERENCES}

Bailey, C. and Zerner, C. 1992. Local management of fisheries resources in Indonesia: opportunities and constraints. In Pollnac, R.B., C. Bailey and A. Poernomo, Contributions to Fishery Development Policy in Indonesia. Central Research Institute for Fisheries, Jakarta, Indonesia. p 38.56

Caddy, J.F. 1982. Some Considerations Relevant to the Definition of Shared Stocks and Their Allocation Between Adjacent Economic Zones. FAO Fish. Circ. 749. $44 \mathrm{pp}$.
Giesen, W. and Sukotjo. 1991. Conservation and Management of the Ogan-Komering Lebaks, South Sumaterc. PHPA/AWB Sumatera Wetland Project Report No. 8, Bogor, $66 \mathrm{pp}$.

Hoggarth, D.D. and Utomo, A.D. 1994. The fisheries ecology of the Lubuk Lampam river floodplain in South Sumatera, Indonesia. Fish. Res. 20: 191-213.

Hoggarth, D.D. and Kirkwood, G.P. 1996. Technical interactions in floodplain fisheries of south and south-east Asia. In Cowx, I.G. (eds.). Stock Assessment in Inland Fisheries, Fishing News Books, UK. p 280.292

MRAG, 1997. Fisheries Dynamics of Modified Floodplains in Southern Asia, Final Technical Reporl. Fisheries Management Science Programme, ODA, UK. 275pp + app.

Ostrom, E., 1990. Governing the Commons: The Evolution of Institutions for Collective Action. Cambridge University Press, Cambridge, UK. 280 $\mathrm{pp}$.

Vaus, K.F., Sachlan, M. and Wirwatmadja, G. 1953. On the ecology and fisheries of some inland waters along the rivers $\mathrm{Ogan}$ and Komering in $\mathrm{SE}$ Sumatera. Contr. Inl. Fish. Res. Stn. DjakartaBogor, Indonesia 3: 1-32.

Welcomme, R.L. 1985. River Fisheries. FAO Fish Tech. Pap. 262. 330 pp. 